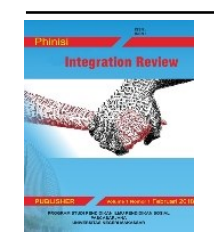

Phinisi Integration Review

Vol. 3, No.2, Agustus 2020 Hal 279-289

Website: http://ojs.unm.ac.id/pir

p-ISSN: 2614-2325 dan e-ISSN: 2614-2317

DOI: https://doi.org/10.26858/v3i2.14921

\title{
Pelaksanaan Tugas Lurah Dalam Pelayanan Masyarakat di Kelurahan Tompobalang Kecamatan Somba Opu Kabupaten Gowa
}

\author{
Muh. Adirudini ${ }^{1}$ Rifdan $^{2}$ Manan Sailan $^{3}$ \\ ${ }^{1}$ Pendidikan Hukum dan Kewarganegaraan, Universitas Negeri Makassar, Indonesia \\ ${ }^{23} \mathrm{Ilmu}$ Pendidikan Sosial,Universitas Negeri Makassar, Indonesia \\ Email: ${ }^{1}$ muhadirudini@gmail.com
}

\begin{abstract}
Abstrak. Penelitian ini bertujuan untuk mengkaji dan mendeskripsikan (1) Pelaksanaan tugas Lurah dalam pelayanan masyarakat di Kelurahan Tompobalang Kecamatan Somba Opu Kabupaten Gowa. (2) Faktor determinan dalam pelayanan masyarakat di Kelurahan Tompobalang Kecamatan Somba Opu Kabupaten Gowa. (3) Strategi pelaksanaan tugas Lurah dalam pelayanan masyarakat di Kelurahan Tompobalang Kecamatan Somba Opu Kabupaten Gowa. Jenis penelitian ini adalah penelitian kualitatif dengan pendekatan fenomenologi, dimana jenis penelitian ini dilakukan dengan mengamati subjek dan objek yang akan diteliti berdasarkan fakta-fakta yang ada. Fakta yang ditemukan dikaji dan dideskripsikan secara mendalam. Teknik pengumpulan data menggunakan observasi, wawancara, dokumentasi, dan dianalisis dengan teknik triangulasi. Hasil penelitian ini menunjukkan bahwa: (1) Pelaksanaan tugas lurah dalam pelayanan masyarakat di Kelurahan Tompobalang mengenai pola-pola tugas Lurah yang efektif dan efesien oleh pemerintah Kelurahan Tompobalang didapati bahwa pola-pola tugas Lurah Tompobalang sudah cukup efektif dan efesien, dimana Lurah selalu mengarahkan dalam memberikan tugas dan arahan yang dapat dimengerti walaupun Lurah tidak selalu berada di kantor dan bertugas diluar, namun dengan kecanggihan teknologi handphone hal tersebut dapat diatasi. (2) Faktor determinan yang dihadapi dalam pelaksanaan tugas lurah adalah sarana dan prasana yang belum memadai sehingga pelayanan masyarakat pun kurang optimal. (3) Strategi pelaksanaan tugas lurah dalam pelayanan masyarakat di Kelurahan Tompobalang yang dilakukan dengan Peningkatan kualitas penyelenggaraan pemerintahan dengan menerapkan Kebijaka Optimalisasi penerapan SOP (Standar Operasional Prosedur) dengan penguatan kualitas dukungan administrasi sarana,dan prasarana di kelurahan Tompobalang.
\end{abstract}

Kata Kunci: Tugas Lurah; Pelayanan masyarakat.

Abstract. This study aims to study and describe (1) how the implementation of the tasks of the Lurah in community service in the Tompobalang Village, Somba Opu District, Gowa Regency. (2) Determinants in the community service in Tompobalang Village, Somba Opu District, Gowa Regency. (3) What is the District, Gowa Regency. This type of research is a qualitative research with a phenomenological approach, where this type of research is carried out by observing the subjects and objects to be examined based on the facts that exist. The facts found were studied and described in depth. Data collection techniques using observation, interviews, documentation, and analyzed with triangulation techniques. The results of this study indicate that: (1) The implementation of the tasks of the Lurah in community service in the Tompobalang Village regarding the effective and efficient patterns of the Lurah's tasks by the government of the Tompobalang Village is found that the patterns of the Tompobalang Urban Village tasks are quite effective and efficient, where 
the Lurah always directs in giving assignments and directions that can be understood even though the headman is not always in the office and outside, but with the sophistication of cellphone technology it can be overcome. (2) The determinants faced in implementing the village head's tasks are facilities that are considered inadequate and administrative arrangements that are still not optimal. (3) Strategy for the implementation of lurah tasks in community service in Tompobalang Kelurahan that is carried out by always fixing the facilities and infrastructure in the kelurahan office, and increasing the ability and performance of the Lurah and the village government officials to the maximum extent in carrying out government administrative tasks, while strengthening community participation and institutions and other aspects of community service.

Keywords: Lurah Task, Community service.

\section{PENDAHULUAN}

Pembangunan nasional merupakan perwujudan tujuan nasional Bangsa Indonesia pada intinya bertujuan untuk mewujudkan masyarakat adil dan makmur yang merata baik materil maupun spiritual berdasarkan Pancasila dan Undang-Undang Dasar 1945. Pembangunan nasional yang dilaksanakan pada hakikatnya mencakup semua aspek kehidupan manusia yang dilakukan secara terarah, terpadu dan berkesinambungan serta menyeluruh keseluruh pelosok tanah air.

Sesuai dengan amanat Undang-Undang Dasar Negara Republik Indonesia Tahun 1945 Pasal 18 Ayat (1) yang menyatakan, bahwa: "Negara Kesatuan Republik Indonesia dibagi atas daerah-daerah provinsi, dan daerah provinsi itu dibagi atas kabupaten dan kota, yang tiap-tiap provinsi, kabupaten, dan kota itu mempunyai pemerintahan daerah, yang diatur dengan undang-undang”. Dalam Ayat (2) pun menengaskan bahwa: "Pemerintahan daerah provinsi, daerah kabupaten, dan kota mengatur dan mengurus sendiri urusan pemerintahan menurut asas otonomi dan tugas perbantuan". Dari pasal di atas, mengandung makna bahwa pemerintahan daerah berwenang untuk mengatur dan mengurus sendiri urusan pemerintahan menurut asas otonomi dan tugas pembantuan. Pemberian otonomi luas kepada daerah diarahkan untuk mempercepat terwujudnya kesejahteraan masyarakat melalui peningkatan pelayanan, pemberdayaan dan peran serta masyarakat.

Secara teoritis, tujuan pelayanan publik pada dasarnya adalah memuaskan masyarakat untuk mencapai kepuasan itu dituntut kualitas pelayanan prima yang tercermin dari asas-asas pelayanan publik berdasarkan Surat Keputusan Menteri Pendayagunaan Aparatur Negara (Kepmen PAN) No. 63 Tahun 2003 tentang Pedoman Umum Penyelenggaraan Pelayanan Publik pada bagian konsideran menyatakan sebagai berikut: (a) kesederhanaan dalam arti bahwa prosedur atau tata cara pelayanan diselenggarakan dengan prosedur mudah, pelayanan lancar, pelayanan cepat dan pelayanan tidak berbelit-belit, (b) kejelasan dan kepastian, dalam arti adanya kejelasan dan kepastian mengenai prosedur/tata cara, persyaratan pelayanan, pengetahuan petugas dan tanggung jawab petugas, (c) keamanan, dalam arti bahwa proses serta hasil pelayanan umum dapat memberikan pelayanan dalam hal: keamanan pelayanan, kenyamanan, kemampuan petugas dan kepastian hukum, (d) keterbukaan, dalam arti prosedur/tata cara persyaratan, satuan kerja/pejabat penanggung jawab pemberi pelayanan umum dalam hal : waktu penyelesaian, kepastian biaya, akurasi system dan fasilitas dan peralatan, (e) efesien dan ekonomis dalam arti persyaratan ringan, kedisiplinan petugas, kewajaran biaya pelayanan dan sesuai kemampuan ekonomis masyarakat, (f) keadilan yang merata dalam arti cakupan/jangkauan pelayanan umum diusahakan: keadilan mendapatkan pelayanan, perhatian terhadap kepentingan masyarakat, kesediaan dan ketanggapan petugas membantu dan pendistribusian yang merata, $(\mathrm{g})$ ketetapan waktu dalam arti implementasi pelayanan umum dapat diselesaikan dalam hal informasi waktu, 


\section{Adirudini, Rifdan, Sailan. Pelaksanaan Tugas Lurah Dalam Pelayanan Masyarakat...}

kecepatan pelayanan, realisasi waktu dan kepastian jadwal pelayanan.

Pada dasarnya pemerintah kelurahan harus melakukan upaya agar menghasilkan pelayanan yang cepat, tepat dan transparan. Pelayanan yang harus ditingkatkan kepada masyarakat merupakan upaya untuk meningkatkan kesejahteraan masyarakat. Salah satu bidang pelayanan masyarakat adalah bidang pelayanan pemerintahan yang merupakan tugas pemerintah khususnya seluruh di kelurahan untuk menyelenggarakannya secara optimal, tapi selama ini masih banyak dikeluhkan oleh masyarakat. Salah satu indikator yang dapat kita lihat dari fenomena ini adalah pada fungsi pelayanan publik yang mendapatkan keluhan dari masyarakat karena belum memperhatikan masyarkat penggunanya, dan pelayanan publik yang masih cenderung bersifat direktif yang hanya memperhatikan atau mengutamakan kepentingan kepemimpinan/organisasi saja.

Kenyataan lain yang sering ditemukan di lapangan bahwa kepemimpinan Lurah pun belum sepenuhnya dapat berjalan optimal dalam pelaksanaan tugas diwilayah kerjanya, serta rendahnya frekuensi kegiatan koordinasi yang dilakukan Lurah terhadap penyelenggaraan pemerintahan. Tuntunan peningkatan kinerja Lurah yang berkualitas semakin dirasakan sangat penting, mengingat kelurahan merupakan unit pemerintahan terkecil setingkat desa yang memberikan kontribusi besar terhadap daerah.

Fenomena yang sering terjadi di Kelurahan ditandai banyaknya prob lem bila berurusan dengan birokrat dalam pengurusan segala bentuk syarat-syarat yang menyangkut dengan kependudukan seperti: kartu keluarga, kartu tanda penduduk, surat pindah, surat miskin, kartu berobat gratis dan tidak adanya fasilitas kotak pengaduan dikantor kelurahan serta rahasia umum dimata masyarakat terhadap rendahnya kualitas pelayanan publik dikarenakan pegawai yang sangat sedikit, kualitas kantor yang dibawah standar dan lain sebagainya.

Permasalahan tersebut relevan terhadap kondisi pada pelayanan masyarakat yang ada pada Kantor Kelurahan Tompobalang Kecamatan Somba Opu Kabupaten Gowa. Berdasarkan hasil studi pendahuluan yang penulis lakukan melalui sebuah observasi ke objek penelitian dengan mencari berbagai sumber yang dapat dipertanggung jawabkan keabsahannya. Dimuat dalam Liputan 4.com Desember 20, 2019 menginformasikan bahwa :"Kisah yang di alami ibu Hanifah warga jalan swadaya mengatakan sudah empat kali datang di Kantor Kelurahan Tompobalang, namun tak satupun perangkap Lurah yang ada di kantor tersebut".

Disamping itu lebih sepesifik lagi ditemukan kurangnya koordinasi, petunjuk kerja dari Lurah sebagai pimpinan kelurahan sering terjadi kebinggunan diantara pegawai karena tidak adanya instruksi atau petunjuk yang jelas dari lurah dalam menyelesaikan permasalahan yang terjadi. Selain itu kurangnya sosialiasasi antara Lurah dan warganya, seperti ada peristiwa banjir, duka yang dialami oleh warga di Kelurahan Tompobalang Kecamatan Somba Opu Kabupaten Gowa dimana Lurah jarang hadir bahkan memberikan sambutan. Dari hal tersebut yang diharapkan Lurah dapat memaksimalkan tugasnya dalam pelayanan masyarakat agar penyelenggaraan pemerintahan kelurahan dapat berjalan optimal, dan kebutuhan masyarakat dalam pelayanan publik dapat terpenuhi.

\section{TINJAUAN PUSTAKA}

\section{A. Otonomi Daerah}

Otonomi daerah merupakan tema lama yang tampaknya selalu menemukan aktualisasi dan relevansinya. Dikatakan tema lama, karena Undang-Undang Dasar 1945 telah memberikan landasan yuridis yang jelas tentang eksitensi otonomi daerah. Seiring dengan ditetapkannya Undang-Undang Dasar Tahun 1945, sejak itu pengaturan tentang pemerintahan daerah dalam perundang-undangan sebagai penjabaran pasal 18, mulai ramai diperdebatkan. Ia menjadi prioritas di antara upaya penyusunan berbagai Undang-Undang sebagai pelaksanaan UndangUndang Dasar Negara Republik Indonesia 1945.Etika Lingkungan

Undang-undang Dasar 1945 sebagai
dasar konstitusional negara kita telah mengamanatkan, bahwa bumi dan air serta kekayaan alam yang terkandung didalamnya dipergunakan sebesar-besarnya untuk kemakmuran rakyat. dengan demikian dalam rangka mendayagunakan sumber daya alam untuk memajukan kesejahteraan umum tersebut dan untuk mencapai kebahagiaan hidup berdasarkan Pancasila, perlu dilaksanakan pembangunan berkelanjutan yang berwawasan lingkungan hidup berdasarkan kebijaksanaan nasional yang terpadu dan menyeluruh dengan memperhitungkan kebutuhan generasi sekarang dan generasi mendatang. 
Dalam UU Nomor 23 Tahun 2014, tujuan otonomi daerah yaitu untuk memberdayakan daerah termasuk masyarakat, peran sertanya menumbuhkembangkan demokrasi, pemerataan dan keadilan serta persatuan dan kesatuan nasional dengan mengingat asal-usul suatu daerah, kemajemukan, karakteristik serta potensi daerah dalam kerangka Negara Kesatuan Republik Indonesia (NKRI).

Dengan demikian, inti konsep pelaksanaan otonomi daerah adalah upaya memaksimalkan hasil yang akan dicapai sekaligus menghindari kerumitan dan hal-hal menghambat pelaksanaan otonomi daerah. Sehingga tuntutan masyarakat dapat diwujudkan secara nyata dengan penerapan otonomi daerah yang luas dan kelangsungan pelayanan publik tidak diabaikan, serta memelihara kesinambungan fisikal daerah. Dengan kata lain mempercepat terwujudnya kesejahteraan melalui peningkatan pelayanan, pemberdayaan dan peran serta masyarakat, serta peningkatan daya saing daerah memperhatikan prinsip demokrasi dan pemerataan keadilan.

B. Konsep dan Teori Tugas Pokok

Adapun definisi tugas menurut para ahli, yaitu Dale Yoder dalam moekijat (1998:9), 'the term rask is frequently used to describe one portion or element in a job" (tugas digunakan untuk mengembangkan satu bagian atau satu unsur dalam suatu jabatan). Sementara Stone dalam moekijat (1998:10) mengemukakan bahwa "A task is specific work activity carried out to achieve a specific purpose" (suatu tugas merupakan suatu kegiatan pekerjaan khusus yang dilakukan untuk mencapai suatu tujuan tertentu).

Prinsip pemerintahan yang berorientasi pada misi tugas pokok, maka perlu dikemukakan pokok-pokok pengertian yang terkandung dalam prinsip ini. Prinsip ini mengarahkan agar penyelenggaraan tugas-tugas biokrasi lebih memusatkan pada tugas pokok organisasi. Dengan demikian tugas-tugas yang tidak produktif dan bukan tugas pokok perlu ditinjau sehingga beban birokrasi dapat dipersempit, dan produktifitas pegawai dapat meningkat. Dengan kata lain lembaga biokrasi perlu kembali berorientasi kepada tugas pokok.

Pemerintahan dalam penyelenggaraan program atau kegiatan haruslah lebih luwes (fleksible), dengan melihat kondisi lokal. Jadi cara penyelenggaraan tugas dapat disesuaikan sejauh lebih menjamin pencapaian misi organiasasi. Prinsip misi juga menuntut agar tidak terlalu banyak mengatur teknis, sehingga terdapat keluwesanan dalam pencapaian sasaran pokok. Aturan biokrasi yang berbelit-belit perlu disederhanakan sehingga penyelenggaraan tugas dapat lebih lancar, efisien dan lebih mendukung kelancaran pencapaian misi. Bertolak dari tuntutan prinsip tersebut, maka pemerintahan berdasarkan misi menuntut pemahaman terhadap kebutuhan (need) konsumen/masyarakat dan tentunya didahului dengan identifikasi kebutuhan masyarkat yang dilayani.

\section{Tata Kelola Pemerintahan Yang Baik (Good} Governance)

Penerapan terhadap prinsip-prinsip good governance berkenaan dengan penyelenggaraan tiga tugas dasar pemerintah yaitu: a) menjamin keamanan setiap orang dan masyarakat; b) mengelola suatu struktur efektif untuk sektor publik, sektor dan sektor masyarkat; c) memajukan saran ekonomi, sosial dan bidang lainnya dengan kehendak rakyat.

Sementara itu, Pasal 3 Undang-Undang Nomor 28 Tahun 1999 tentang Penyelenggaraan Negara yang Bersih dan Bebas dari Korupsi, Kolusi dan Nepotisme, telah menetapkan beberapa asas penyelenggaraan Negara yang bersih. Asas umum penyelenggaraan Negara tersebut meliputi: (a) Asas kepastian hukum adalah asas dalam Negara hokum yang mengutamakan landasan peraturan perundang-undangan, kepatutan, dan keadilan dalam setiap kebijakan penyelenggara Negara. (b)Asas tertib penyelenggara negara adalah asas yang menjadi landasan keteraturan, keserasian, dan keseimbangan dalam pengendalian penyelenggara negara. (c) Asas kepentingan umum adalah asas yang berdasarkan pada wewenang negara untuk melindungi dan mengatur kepentingan dalam kehidupan masyarakat. (d)Asas keterbukaan adalah asas yang membuka diri terhadap masyarakat untuk memperoleh informasi yang benar, jujur, dan tidak diskriminatif tentang penyelengaraan negara dengan tetap memperhatikan perlindungan atas hak pribadi, golongan dan rahasia negara. (e) Asas proporsionalitas adalah asas yang mengutamakan keseimbangan antara hak dan kewajiban penyelenggara negara. (f) Asas profesionalitas adalah hak yang mengutamakan keahlian yang berlandaskan kode etik, dan ketentuan perundang-undangan yang berlaku. (g) Asas akuntabilitas adalah asas yang menentukan bahwa setiap kegiatan dan hasil akhir dari kegiatan penyelenggaraan negara harus dapat dipertanggungjawabkan kepada masyarakat atau rakyat sebagai pemengan 
kedaulatan tinggi negara sesuai dengan ketentuan peraturan perundang-undangan yang berlaku.

\section{METODE PENELITIAN}

Penelitian ini termasuk jenis penelitian kualitatif yaitu mengkaji hasil penelitian dengan menguraikan data aktual yang diperoleh dalam proses penelitian. Penelitian ini bersifat deskriptif yang bermaksud untuk mengakaji Pelaksanaan Tugas Lurah dalam Pelayanan Mayarakat Di Kelurahan Tompobalang Kecamatan Somba Opu Kabupaten Gowa.

Penelitian ini dilakukan di Lokasi penelitian diadakan di Kantor Kelurahan Tompobalang Kecamatan Somba Opu Kabupaten Gowa.

Sumber data dalam penelitian ini adalah sebagai berikut: (a) Data primer adalah data yang diperoleh secara langsung dari informan (Lurah Kelurahan Tompobalang, sekertaris Kelurahan Tompobalang, pegawai Kelurahan Tompobalang, dan Masyarakat setempat kelurahan Kelurahan Tompobalang.; dan b) data sekunder adalah data yang diperoleh dari berbagai sumber, seperti buku, jurnal, artikel, dan penelitian ilmiah.

Instrument penelitian dalam penelitian ini adalah peneliti sendiri dengan beberapa instrument pendukung seperti tape recorder, kamera dan buku catatan serta pedoman wawancara. Adapun Teknik pengumpulan data yang dilakukan peneliti dalam pengumpulan data penelitian ini adalah ; (a) Observasi; (b) wawancara; (c) dokumentasi.

Teknik analisis data yang digunakan peneliti menggunakan model Miles and Huberman. Analisis data dalam penelitian kualitatif dilakukan saat pengumpulan data berlangsung, dan setelah selesai pengumpulan data dalam periode tertentu. Analisis data yang digunakan terdiri dari tiga alur kegiatan, yaitu sebagai berikut: (a) Reduksi data; (b) Penyajian data; (c) Menarik kesimpulan dan verifikasi.

Peneliti melakukan teknik pemeriksaan dan keabsahan data dengan uji kredibilitas sebagai berikut : (a) Perpanjangan pengamatan; (b) Meningkatkan ketekunan; (c) Triangulasi; (d) member check.

\section{HASIL PENELITIAN}

Untuk mengetahui bagaimana Pelaksanaan Tugas Lurah dalam Pelayanan Masyarakat di Kelurahan Tompobalang kecamatan Somba Opu Kabupaten Gowa. Untuk lebih jelasnya akan diuraikan secara terperinci hasil wawancara sebagai berikut.

\section{Pelaksanaan Tugas Lurah dalam Pelayanan Masyarakat di Kelurahan Tompobalang Kecamatan Somba Opu Kabupaten Gowa}

Dengan dikeluarkannya Undang-Undang Nomor 23 Tahun 2014 tentang Pemerintahan Daerah Pasal 229 dijabarkan mengenai kelurahan yakni Lurah diangkat selaku kepala kelurahan serta perangkat kecamatan dan bertanggung jawab kepada Camat dan dilantik oleh Bupati/Walikota serta bertugas membantu Camat dalam banyak hal termasuk di dalamnya dibidang pelayanan masyarakat.

Adapun tugas pokok Lurah dalam menyelenggarakan kegiatan pelayanan masyarakat berdasarkan Peraturan Pemerintahan Nomor 73 Tahun 2005 tentang Kelurahan pada Pasal 5 yang mengatur bahwa: (1) dalam melaksanakan tugas pokok sebagaimana yang dimaksud dalam pasal 4, Lurah mempunyai tugas: (c) pelayanan masyarakat.

Kelurahan Tompobalang memiliki standar pelayanan yang jelas dan mengacu pada Peraturan Daerah Kabupaten Gowa Nomor 5 Tahun 2001 tentang Pembentukan Organisasi dan Tata Kerja Kecamatan dan Kelurahan. Standar pelayanan tersebut meliputi prosedur pelaksanaan kegiatan adminitrasi masyarakat dan pelaksanaan kegiatan program kerja dari hasil musyawarah rencana pembangunan.

Sebagai pelayan, pengayom, penggerak prakarsa, Lurah bertanggung jawab dalam menjalankan pemerintahnya ditingkat kelurahan sehingga benar-benar dituntut bekerja secara professional yang diimbangi dengan kualitas sumber daya manusia yang memadai serta sarana dan prasarana yang mendukung.

Berdasarkan wawancara dengan bapak Muhammad Rivan Maulana selaku Lurah Tompobalang mengungkapkan mengenai tugas Lurah dalam melaksanakan pelayanan masyarakat di pemerintahan kelurahan bahwa: "Tugas lurah dalam melaksanakan pelayanan masyarakat dilaksanakan berdasarkan peraturan yang ditetapkan oleh Peraturan Pemerintah dan Peraturan Daerah Kabupaten Gowa dengan selalu berkordinasi dengan Pemerintahan Kecamatan Somba Opu melalui rapat yang dilaksanakan tiap bulan di Kantor Kecamatan dan rapat coffee morning tiap minggu I dan minggu III di kantor Kelurahan tiap bulannya. Dan tugas Lurah yang dilaksanakan saat ini telah berjalan 
sesuai rencana serta sudah melaksanakan dengan sepenuhnya sesuai mekanisme terhadap pelaksanaan pelayanan masyarakat di pemerintahan Kelurahan Tompobalang".

Adapun kegiatan berskala yang telah dilaksanakan Lurah Tompobalang Kecamatan Somba Opu untuk selalu meningkatkan pelayanan masyarakat, melalui:

- Rapat yang diadakan secara periodik.

- Kunjungan ke Lingkungan Kelurahan

Tompobalang yang diadakan secara periodik, dengan tujuan:

1) Membahas dan mengetahui sejauhmana pelaksanaan program/kegiatan yang telah ditetapkan setiap Lingkungan Kelurahan Tompobalang;

2) Pemantapan tugas, fungsi dan kewajiban oleh Kepala Lingkungan Kelurahan Tompobalang;

3) Penyelesaian permasalahan yang muncul dalam penyelenggaraan Pemerintahan Kelurahan di tingkatan Lingkungan Kelurahan Tompobalang;

- Melakukan pengawasan terhadap penyelenggaraan pemerintahan kelurahan secara rutin dan berkelanjutan;

Pembinaan Lingkungan, Rukun warga (RW) dan Rukun Tetangga (RT) dilakukan karena posisi Kepala Lingkungan, RW/RT sebagai garda terdepan dalam mendukung penyelenggaraan Pemerintahan Kelurahan Tompobalang dan kelancaran pelayanan kepada masyarakat;

Berikut ini akan diuraikan tugas pokok Lurah dalam menyelenggarakan pelayanan masyarakat di Kelurahan Tompobalang Kecamatan Somba Opu Kabupaten Gowa yaitu:

\section{a. Tugas Lurah dalam pelayananan kegiatan adminstratif masyarakat}

Sebagai unit pelaksana pemerintahan yang terendah dibawah kecamatan, jenis-jenis pelayanan yang dapat dikoordinasikan penyelenggaraannya oleh Lurah adalah beragam dengan kriteria yang mencakup pelayanan administrasi masyarakat; seperti pelayanan kelengkapan data untuk pembuatan KTP, pencatatan akta tanah, pelayanan surat keterangan IMB, surat keterangan kelahiran, surat keterangan kematian, surat keterangan usaha, surat keterangan keramaian, surat keterangan izin nikah, surat keterangan belum nikah, surat keterangan kewarisan, dan sebagainya.

Dari sekian banyak bentuk-bentuk pelayanan yang diberikan kelurahan Tompobalang kepada masyarakat, maka peneliti mengkaji berupa:

1) Pelayanan Kartu Tanda Penduduk /Kartu Keluarga

Dasar hukum dalam pemberian pelayanan kepada masyarakat adalah yaitu standar operasional pelayanan (SOP). Untuk Kartu Tanda Penduduk dan Kartu Keluarga berdasarkan Perda Kabupaten Gowa Nomor 5 Tahun 2008 tentang Penyelenggaran Administrasi Kependudukan dan Catatan Sipil di Kabupaten Gowa.

Adapun tugas Lurah dalam pelaksanaan pelayanan masyarkat di kelurahan Tompo Balang khusus pelayanan kartu tanda penduduk dan kartu keluarga dengan pemberian surat pengantar kelurahan yang membutuhkan tanda tangan pak lurah yang kemudian di urus oleh staf bagian pelayanan masyarakat, untuk selanjutnya dibawa ke kantor catatan sipil kabupaten gowa.

2) Pelayanan Izin Mendirikan Bangunan

Mengacu kepada Peraturan Daerah No. 18 Tahun 2001 tentang Retribusi Izin Mendirikan Bangunan (IMB) pada Bab IV Ketentuan Pemberian Izin Mendirikan Bangunan Pasal 6 menyatakan "setiap mendirikan atau mengubah bangunan di wilayah Kabupaten Gowa terlebih dahulu harus mendapat izin dari Kepala Daerah. Izin sebagaimana dimaksud diberikan berkan permohonan secara tertulis yang diketahui oleh Lurah dan Camat. Permohonan izin tersebut memuat keterangan tentang: 1) nama, alamat dan pekerjaan pemohon; 2) status, letak dan luas tanah yang akan dibanguni; 3) jenis bangunan; 4) gambar rencana bangunan beserta konstruksi dan bahan bangunan yang digunakan; 5) Rencana Anggaran Bangunan (RAB); 6) materai Rp. 6.000; dan 7) keterangan lainnya seperti salinan surat bukti hak atas tanah, KTP, tanda pelunasan PBB dan baestek bangunan.

Adapun tugas Lurah dalam pelaksanaan pelayanan kepada masyarkat khusus pelayanan Izin Mendirikan Bangunan (IMB) dengan pemberian surat keterangan IMB dari Kelurahan Tompobalang yang membutuhkan tanda tangan pak lurah yang yang kemudian di urus oleh staf bagian pelayanan masyarakat, untuk selanjutnya dibawa ke kantor Kecamatan Somba Opu Kabupaten Gowa. 


\section{Adirudini, Rifdan, Sailan. Pelaksanaan Tugas Lurah Dalam Pelayanan Masyarakat...}

Mengenai kendala yang dihadapi masyarakat dalam kegiatan administrasi pengurusan surat keterangan IMB maka Lurah memberikan pengertian kepada masyarakat, meminta masyarakat melampirkan persyaratan yang diminta agar yang di urus dapat berjalan dengan lancar dan mengarahkan aparat Kelurahan Tompobalang untuk menghadapi masyarakat dengan sabar yang terkadang melakukan klaim atas ketidakpuasan terhadap pelayanan yang diperoleh.

Berdasarkan wawancara dengan bapak Muhammad Rivan Maulana selaku Lurah Tompobalang mengungkapkan mengenai tugas Lurah dalam melaksanakan pelayanan masyarakat di pemerintahan kelurahan bahwa:

"Tugas lurah dalam melaksanakan pelayanan administrasi masyarakat di Pemerintahan Kelurahan Tompobalang dilaksanakan berdasarkan peraturan yang ditetapkan oleh Peraturan Daerah Kabupaten Gowa dengan mencantumkan semua persyaratan yang dibutuhkan agar dapat di proses dan berjalan mudah sesuai yang diharapkan".

Pengelolaan kegiatan administrasi masyarakat pada pemerintahan kelurahan melalui

\begin{tabular}{|c|c|c|c|}
\hline No & Program Kerja & Tahun & Status \\
\hline \multirow{6}{*}{1} & Pengerjaan & \multirow{6}{*}{2019} & \multirow{6}{*}{ Terlaksana } \\
\hline & Pepin jalan & & \\
\hline & 500 meter di & & \\
\hline & lingkungan & & \\
\hline & cambaya jalan & & \\
\hline & swadaya 3 & & \\
\hline \multirow[t]{6}{*}{2} & Pembuatan & \multirow{6}{*}{2019} & \multirow{6}{*}{ Terlaksana } \\
\hline & drainase & & \\
\hline & (selokan) di & & \\
\hline & lingkungan & & \\
\hline & je'ne berang & & \\
\hline & 350 meter jalan & & \\
\hline \multirow{4}{*}{3} & Penambahan & 2019 & Terlaksana \\
\hline & bak & & \\
\hline & penampungan & & \\
\hline & air & & \\
\hline \multirow[t]{3}{*}{4} & Perbaikan & 2019 & Terlaksana \\
\hline & kantor & & \\
\hline & kelurahan & & \\
\hline \multirow[t]{4}{*}{5} & Sarana air & 2019 & Terlaksana \\
\hline & bersih di & & \\
\hline & lingkungan & & \\
\hline & je'ne berang & & \\
\hline \multirow[t]{2}{*}{6} & Pembukaan & 2019 & Tidak \\
\hline & jalan stapak & & terlaksana \\
\hline \multirow[t]{4}{*}{7} & Perbaikan & 2019 & Tidak \\
\hline & tanggul sungai & & terlaksana \\
\hline & je'ne berang & & \\
\hline & yang 20 meter & & \\
\hline
\end{tabular}

analisis potensi daerah, beban kerja daerah dengan memperhatikan prinsip-prinsip efektivitas, efisiensi, responsivitas, fleksibilitas, rasionalitas, rentang kendali dan akuntabilitas sehingga harusnya terlaksana pelayanan masyarakat dengan tertib, efesien dan mudah sehingga dapat terwujudnya kegiatan administrasi pemerintahan kelurahan yang baik.

b. Tugas Lurah dalam pelayanan masyarakat di bidang pembangunan

$$
\text { Ditetapkannnya Undang-Undang }
$$

Nomor 25 Tahun 2004 Tentang Sistem Perencanaan Pembangunan Nasional mengamanatkan bahwa setiap daerah harus menyusun rencana pembangunan daerah secara sistematis, terarah, terpadu, dan tanggap terhadap perubahan (pasal 2 ayat 2), dengan jenjang perencanaan jangka panjang (25 tahun), jangka menengah (5 tahun) maupun jangka pendek atau tahunan (1 tahun), serta Undang-Undang Nomor 23 Tahun 2014 tentang Pemerintahan Daerah Bab VII Pasal 150 bahwa daerah wajib memiliki dokumen rencana pembangunan jangka panjang daerah (RPJPD), rencana pembangunan jangka menengah daerah (RPJMD), dan rencana kerja pemerintah daerah (RKPD).

Undang-Undang Nomor 25 Tahun 2004 tentang Sistem Perencanaan Pembangunan Melembagakan Musrenbang di semua peringkat pemeritahan dan perencanaan jangka panjang, jangka menengah, dan tahunan. Musyarawarah rencana pembangunan merupakan kegiatan tahunan yang diadakan pada setiap kelurahan termasuk Kelurahan Tompobalang. Secara keseluruhan penyelenggaraan kegiatan pada bidang pemerintahan dalam hal pelayanan masyarakat di Kelurahan Tompobalang juga telah mengacu pada peraturan daerah. Pemerintah telah menetapkan program kerja yang telah disusun berdasarkan aspirasi masyarakat.

semua masukan masyarakat tentang apa-apa saja yang perlu dibenahi kemudian kami buatkan sebagai rencana program kerja selanjutnya"oleh saya sendiri, kepala lingkungan, ketua RT dan RW, dan pejabat pemerintah yang lainnya. jadi dalam musrembang ini kami biasanya menghimpun semua masukan masyarakat tentang apa-apa saja yang perlu dibenahi kemudian kami buatkan sebagai rencana program kerja selanjutnya"

Kelurahan Tompobalang akan di uraikan dalam tabel 4.6 sebagai berikut: 
Berdasarkan tabel 4.6 tersebut diatas dapat di uraikan bahwa pelaksanaan pencapaian program kerja dari kegiatan musrembang tahun 2019 di Kelurahan Tompobalang merupakan tugas Lurah dalam mengadakan dan menjalankan pelayanannya kepada masyarakat cukup terlaksana secara optimal, ditandai dengan adanya beberapa program kerja yang terlaksanakan seperti pengerjaan pepin jalan, pembuatan drainase (selokan), penambahan bak penampungan air, perbaikan kantor kelurahan, dan sarana air bersih di lingkungan je'ne berang.

\section{Hambatan Pelaksanaan Tugas Lurah dalam Pelayanan Masyarakat di Kelurahan Tompobalang}

Peraturan perundang-undangan yang telah dikemukakan, tidak lain dimaksudkan untuk mengatur tugas Lurah dalam urusan pelayanan masyarakat agar tetap berjalan dengan baik dan sesuai dengan aturan yang ada. Namun dengan adanya peraturan khusus yang mengatur mengenai tugas Lurah, tidak berarti pelaksanaan terhadap pelaksaan tugas lurah dalam hal pelayanan masyarakat terlaksana seperti yang diinginkan sesuai dengan undang-undang pemerintahan daerah, akan tetapi ada beberapa penghambat yang dihadapi dalam pelaksanaan tugas Lurah di kelurahan. Adapun faktor determinan dalam pelaksaan tugas Lurah dalam hal pelayanan masyarakat di Kelurahan Tompobalang adalah hambatan terkait sarana dan prasarana belum memadai.

Perkembangan suatu daerah diiringi pula dengan peningkatan aktivitas pelayanan masyarakat. Peningkatan aktivitas pelayanan masyarakat menimbulkan perubahan-perubahan fisik lingkungan yang secara tidak sadar juga memberikan suatu permasalahan. Salah satu permasalahan yang timbul adalah masalah kondisi tempat pelayanan masyarakat. Pelayanan masyarakat yang baik, dapat dilihat dari sarana dan prasarana yang ada.

Minimnya sarana dan prasarana Kelurahan Tompobalang ini menyebabkan pelayanan masyarakat yang diberikan oleh pegawai di Kantor Kelurahan kepada masyarakat menimbulkan beberapa keluhan dikerenakan pelayanan masyarakat yang kurang optimal. Serta penyaluran bantuan kesejahteraan yang dianggap kurang optimal oleh masyarakat.

Pelaksanaan pembangunan sarana dan prasarana merupakan salah satu faktor yang sangat berpengaruh untuk kelancaran pelaksanaan tugas kelurahan dalam hal pelayanan masyarakat. Pembangunan sarana dan prasarana kelurahan serta pemberdayaan masyarakat harus saling terpenuhi meski pun dalam pelaksanaannya khususnya di Kelurahan Tompobalang masih terhambat oleh beberapa faktor terkait pengelolaan administrasi sehingga sarana dan prasarana dianggap masih belum memadai. Hal ini di tandai dengan masih kurangnya papan informasi yang terpajang, kotak saran belum ada, masih minimnya jumlah komputer yang di gunakan, kurangnya fasilitas masyarakat seperti bangku untuk menunggu pelayanan, dan juga ruangan yang masih kurang efisien dalam hal fasilitas pelayanan masyarakat. Berdasarkan hasil wawancara dengan Muhammad Rivan Maulana selaku Lurah Tompobalang menyatakan bahwa: "Sarana dan prasarana selalu kami upaya untuk terpenuhi di kantor ini agar proses pelayanan masyarakat selalu lancar dan tanpa kendala sebab sarana dan prasarana merupakan hal yang sangat penting dalam peningkatan kinerja kelurahan". Hasil penelitian di Kelurahan Tompobalang menunjukkan bahwa faktor determinan dalam pelaksanaan tugas lurah dalam hal pelayanan masyarakat adalah hambatan mengenai sarana dan prasana yang masih belum memadai yang ditandai dengan keluhan masyarakat terkait papan informasi yang masih kurang, kursi dan keadaan ruangan pelayanan masyarakat yang masih belum memadai, minimnya jumlah komputer yang tersedia, dan masalah kelengkapan sarana administrasi di tandai dengan masih kurangnya catatan pembukuan terkait pelayanan masyarakat, dan adapun catatan pendataan juga masih belum dapat dikatakan rapi.

\section{Strategi Pelaksanaan Tugas Lurah dalam Pelayanan Masyarakat di Kelurahan Tompobalang}

Strategi pelaksanaan tugas Lurah yang dapat dilakukan dalam hal memaksimalkan pelayanan masyarakat di Kelurahan Tompobalang tidak akan terlepas dari visi yang dirumuskan oleh kelurahan yaitu "Terwujudnya Tata Kelola Pemerintahan Yang Profesional dan Inovatif menuju Masyarakat yang mandiri"yang selanjutnya visi tersebut dijabarkan dalam beberapa misi salah satu diantaranya yaitu meningkatkan kualitas pelayanan administrasi,kesejahteraan masyarakat,ketentraman dan ketertiban masyarakat. 


\section{Adirudini, Rifdan, Sailan. Pelaksanaan Tugas Lurah Dalam Pelayanan Masyarakat...}

dalam hal ini, Berdasarkan hasil wawancara dengan Muhammad Rivan Maulana selaku Lurah Tompobalang menyatakan bahwa: "mengenai strategi untuk meningkatkan kualitas pelayanan masyarakat acuan kita adalah berdasarkan visi dan misi yang telah dirumuskan. Selain itu tujuan kita juga merupakan impelemntasi dari pernyataan misi yang akan dicapai atau dihasilkan nanti. Jadi sasaran kita terhadap pelayanan masyarakat adalah meningkatkan kualitas pelayanan publik"

Dalam hal ini telah jelas dijabarkan berdasarkan pada penjabaran visi dan misi serta tujuan maka, kelurahan tompobalang merumuskan strategi dan kebijakan dalam pencapaian visi.

-Sasaran : Peningkatan kualitas penyelenggaraan pelayanan publik pemerintahan kelurahan Tompobalang.

-Strategi : Peningkatan kualitas penyelenggaraan pemerintahan

-Kebijakan : Optimalisasi penerapan SOP (Standar Operasional Prosedur) dengan penguatan kualitas dukungan administrasi,sarana,dan prasarana.

Selain itu, peningkatan partisipasi masyarakat dalam pelayanan masyarakat dalam rangka mewujudkan transparansi dan akuntabilitas dalam pelaksanaan pelayanan masyarakat, dikembangkan dengan suatu konsep dengan membangun keterlibatan/partisipasi masyarakat dalam menyeleggarakan fungsi-fungsi pelayanan masyarakat dalam pembangunan di samping masyarakat dapat berpartisipasi penuh dan melakukan pengawasan sosial.

\section{PEMBAHASAN}

\section{Pelaksanaan Tugas Lurah dalam} Pelayanan Masyarakat di Kelurahan Tompobalang Kecamatan Somba Opu Kabupaten Gowa

Tugas pokok Lurah dalam menyelenggarakan kegiatan pelayanan masyarakat berdasarkan Peraturan Pemerintahan Nomor 73 Tahun 2005 tentang Kelurahan pada pasal 5 yang mengatur bahwa: (1) dalam melaksanakan tugas pokok sebagaimana yang dimaksud dalam pasal 4, lurah mempunyai tugas: (c) pelayanan masyarakat.

Berikut ini akan diuraikan tugas pokok Lurah dalam menyelenggarakan pelayanan masyarakat di Kelurahan Tompobalang Kecamatan Somba Opu Kabupaten Gowa yaitu:
(1)Pelaksanaan kegiatan adminstratif masyarakat. (2) Tugas Lurah dalam pelayanan masyarakat di bidang pembangunan Dalam pelaksanaan tugas Lurah dalam hal pelaksanaan kegiatan adminstratif masyarakat di Kelurahan TompoBalang belum terlaksana dengan baik. ketentuan mengenai pelaksanaan adminstratif di Kelurahan Tompobalang telah diatur dan memiliki standar pelayanan yang jelas dan terlihat pada Peraturan Daerah Kabupaten Gowa. Standar ini meliputi prosedur pelaksanaan kegaitan adminitrasi masyarakat baik prosedur pelayanan, waktu pelayanan, biaya pelayanan, sarana prasarana, dan kompetensi petugas pelayanan. Selain itu pelaksanaan tugas lurah di kelurahan Tompobalang dalam pelayanan masyarakat terkait pengurusan surat pengantar kartu tanda penduduk, dan surat perizinan membangun bangunan masih terdapat beberapa kendala yang ditimbulkan baik dari pihak masyarakat maupun pihak kelurahan. Mayoritas masyarakat dikelurahan TompoBalang kurang mengetahui standar operasional pelayanan yang diterapkan oleh kantor Kelurahan Tompobalang. Hal tersebut yang menjadi kendala dalam hal pelaksanaan tugas lurah dalam pelayanan masyarakat

Sedangkan terkait Tugas Lurah dalam pelayanan masyarakat di bidang pembangunan di Kelurahan Tompobalang telah terlaksana cukup baik, hal tersebut di tandai dengan partisipasi aktif staf kelurahan Tompobalang yang langsung turut memantau program kerja yang telah di atur dan juga partisipasi aktif masyarakat dalam pelaksanaan pembangunan di kelurahan Tompobalang. Hal tersebut juga ditandai dengan adanya beberapa program kerja yang terlaksanakan seperti pengerjaan pepin jalan, pembuatan drainase (selokan), penambahan bak penampungan air, perbaikan kantor kelurahan, dan sarana air bersih di lingkungan je'ne berang dan beberapa program kerja yang belum terlaksana yaitu Perbaikan tanggul sungai je'ne berang yang 20 meter.

Sehingga kelurahan di TompoBalang, dalam hal pelaksanaan tugas lurah dalam pelayanan masayarakat dapat dikatakan telah berjalan dengan cukup baik dengan beberapa kendala yang masih bisa di atasi oleh pemerintahan di kelurahan.

\section{Hambatan Pelaksanaan Tugas Lurah dalam Pelayanan Masyarakat di Kelurahan Tompobalang}




\section{Sarana dan Prasarana yang belum memadai}

Pelaksanaan pembangunan sarana dan prasarana merupakan salah satu faktor yang sangat berpengaruh untuk pelaksanaan tugas Lurah dalam hal pelayanan masyarakat. Hal tersebut juga telah diatur dalam Peraturan Menteri dalam Negeri Nomor 130 Tahun 2018 tetang Pembangunan Sarana dan Prasarana Kelurahan serta Pemberdayaan Masyarakat, akan tetapi dalam pelaksanaannya khususnya di Kelurahan Tompobalang masih dihambat oleh sarana dan prasarana yang masih belum memadai.

Hasil penelitian di Kelurahan Tompobalang menunjukkan bahwa faktor determinan dalam pelaksanaan tugas lurah dalam hal pelayanan masyarakat adalah hambatan mengenai sarana dan prasana yang masih belum memadai yang ditandai dengan keluhan masyarakat terkait papan informasi yang masih kurang, kursi dan keadaan ruangan pelayanan masyarakat yang masih belum memadai, minimnya jumlah komputer yang tersedia, dan masalah kelengkapan sarana administrasi di tandai dengan masih kurangnya catatan pembukuan terkait pelayanan masyarakat, dan adapun catatan pendataan juga masih belum dapat dikatakan rapi.

Faktor determinan pelaksanaan tugas lurah di kelurahan TompoBalang, yang telah dijelaskan diatas merupakan masukan yang sangat penting dalam pelaksanaan pelayanan masyarakat. dalam hal ini kelurahan tompobalang masih terus menigkatkan kinerja dalam pelaksanaan tugas lurah dengan terus membenahi permasalahan yang ada secara bertahap dengan mengelola anggaran dengan lebih baik lagi terkait masalah sarana dan prasaran di kelurahan TompoBalang untuk mewujudkan pelayanan masyarakat yang optimal.

\section{Strategi Pelaksanaan Tugas Lurah dalam Pelayanan Masyarakat di Kelurahan Tompobalang}

Pembangunan nasional yang multi dimensi secara pengelolaannya melibatkan segenap aparat pemerintahan, baik ditingkat pusat maupun ditingkat daerah bahkan sampai ditingkat kelurahan. Komponen atau aparat dimaksud hendaknya memiliki kemampuan yang optimal dalam pelaksanaan tugasnya. Mengingat kompleksnya aspek-aspek atau bidang yang hendak dibangun ditingkat pemerintahan terendah tersebut, maka salah satu aspek yang terlebih dahulu perlu dibangun adalah peningkatan kemampuan Lurah serta aparat pemerintah kelurahan dalam pelaksanaan tugastugas administrasi pemerintahan, disamping memperkuat partisipasi masyarakat dan kelembagaannya serta aspek-aspek pelayanan masyarakt lainnya.

Hal tersebut sangat penting, karena Lurah beserta aparatnya adalah sebagai administrator penyelenggara utama aktifitas pemerintahan, pembangunan dan kemasyarakatan maupun sebagai pembina ketentraman dan ketertiban di wilayah kekuasaannya. Begitupun pada Kelurahan Tompobalang dimana peranan Lurah demikian penting dan banyak menentukan maju mundurnya suatu unit pemerintahan kelurahan. Oleh sebab itu diperlukan Lurah yang benarbenar mampu dan dapat bekerjasama dalam pelaksanaan tugas yang menjadi tanggung jawabnya.

Strategi pelaksanaan tugas Lurah pada Kelurahan Tompobalang yang dapat dilakukan dalam hal memaksimalkan pelayanan masyarakat di Kelurahan Tompobalang yaitu Peningkatan kualitas penyelenggaraan pemerintahan dengan menerapkan Kebijaka Optimalisasi penerapan SOP (Standar Operasional Prosedur) dengan penguatan kualitas dukungan administrasi,sarana,dan prasarana di kelurahan tompobalang.

\section{SIMPULAN DAN SARAN}

Berdasarkan hasil penelitian Pelakasnaan Tugas Lurah Dalam Pelayanan Masyarakat di Kelurahan Tompobalang Kecamatan Somba Opu Kabupaten Gowa, penulis dapat mengambil kesimpulan sebagai berikut : (1)Pelaksanaan Tugas Lurah sudah berjalan cukup baik tandai dengan partipasi aktif staf dan masyarakat dalam penyelenggaraan pelayanan masyarakat. (2) Faktor determinan yang mempengaruhi proses pelayanan masyarakat yaitu hambatan mengenai Sarana dan prasarana belum memadai. (3) Strategi yang di lakukan oleh kelurahan Tompobalang yaitu dengan Peningkatan kualitas penyelenggaraan pemerintahan dengan menerapkan Kebijaka Optimalisasi penerapan SOP (Standar Operasional Prosedur) dengan penguatan kualitas 
Adirudini, Rifdan, Sailan. Pelaksanaan Tugas Lurah Dalam Pelayanan Masyarakat...

dukungan administrasi,sarana,dan prasarana di kelurahan tompobalang.

Saran yang dapat penulis berikan kepada pemerintah Kelurahan Tompobalang dalam rangka pelayanan masyarakat adalah sebagai berikut: (1)Menyampaikan pengawasan melekat dan disiplin yang rutin, beserta bentuk-bentuk pengawasan dan maksud tujuan pengawasan yang diterapkan pemerintah Kelurahan Tompobalang. (2) Memantau berjalannya SOP Kelurahan Tompobalang yang telah ditentukan dari kecamatan setempat dalam pelaksanaan tugas lurah dalam pelayanan masyarakat secara optimal. (3) Lebih proaktif dalam memberikan intruksi kepada staf Kelurahan Tompobalang untuk mengawasi kinerjanya dalam pelayanan masyarakat secara maksimal.

\section{DAFTAR RUJUKAN}

Undang-Undang Dasar Negara Republik Indonesia Tahun 1945. Jakarta.

Undang-Undang Nomor 23 Tahun 2014 Tentang Pemerintahan Daerah. Jakarta.

Undang-Undang Nomor 05 Tahun 2014 Tentang Aparatur Sipil Negara. Jakarta.

Peraturan Pemerintah Nomor 73 Tahun 2005 Tentang Kelurahan. Jakarta.

Keputusan Menteri Nomor 63 Tahun 2003

Tentang Pendayagunaan Aparatur Negara. Jakarta. 